\title{
Addictive Genes and the Relationship to Obesity and Inflammation
}

\author{
David Heber • Catherine L. Carpenter
}

Received: 13 December 2010 / Accepted: 29 March 2011 / Published online: 19 April 2011

(C) The Author(s) 2011. This article is published with open access at Springerlink.com

\begin{abstract}
There is increasing evidence that the same brain reward circuits involved in perpetuating drug abuse are involved in the hedonic urges and food cravings observed clinically in overweight and obese subjects. A polymorphism of the D2 dopamine receptor which renders it less sensitive to dopamine stimulation has been proposed to promote self-stimulatory behavior such as consuming alcohol, abusing drugs, or binging on foods. It is important to determine how this polymorphism may interact with other well-known candidate genes for obesity including polymorphisms of the leptin receptor gene and the opiomelanocortin gene. Leptin is a proinflammatory cytokine as well as a long-term signal maintaining body fat. Upper-body obesity stimulates systemic inflammation through the action of multiple cytokines including leptin throughout many organs including the brain. The association of numerous diseases including diabetes mellitus, heart disease, as well as depression with chronic low-grade inflammation due to abdominal obesity has raised the possibility that obesity-associated inflammation affecting the brain may promote addictive behaviors leading to a self-perpetuating cycle that may affect not only foods but addictions to drugs, alcohol, and gambling. This new area of interdisciplinary research holds the promise of developing new approaches to treating drug abuse and obesity.
\end{abstract}

Keywords Food addiction - Genetics · Dopamine - Obesity Drug abuse $\cdot$ Inflammation

\section{Heber $(\bowtie) \cdot$ C. L. Carpenter}

Center for Human Nutrition,

David Geffen School of Medicine at UCLA,

Los Angeles, CA 90095, USA

e-mail: dheber@mednet.ucla.edu

\section{Introduction}

Addiction is an acquired, chronic relapsing disorder that begins with some experimentation and pleasurable responses and, for subgroups of individuals, is followed by preoccupation, escalation, tolerance, denial, and a series of medical, psychological, and social consequences that relate directly to the continued addictive behaviors. Discoveries over the last 20 years have clearly defined a relationship between obesity and systemic inflammation. The association of numerous diseases including diabetes mellitus, heart disease, common forms of cancer, as well as depression and Alzheimer's disease with chronic low-grade systemic inflammation due to abdominal obesity has raised the possibility that obesity-associated inflammation affecting the brain may promote addictive behaviors leading to a self-perpetuating cycle that may affect not only foods but addictions to drugs, alcohol, and gambling.

A key element of chronic addictions is continued addictive behavior in the face of clear knowledge of the expected consequences. Many obese individuals identify specific foods that promote continued consumption in the face of the known consequences of obesity. Yet they feel powerless to control these urges. While for many individuals, these are simply bad habits that can be changed; there is increasing evidence suggesting that genes implicated in other addictive behaviors may also be associated with food addiction, most commonly to sweet and fat foods. Specific associations of genetic polymorphisms of the dopamine, opiomelanocortin, and leptin receptor have been hypothesized to increase the risk of food addiction. Exercise and regular physical activity can entrain some of the same reward pathways and its efficacy in maintaining body weight after weight loss may be due to the activation of neural pathways involved in the initiation of overeating. Insights into the 
genetics of addictive behaviors associated with obesity may both lead to improved therapies of obesity and at same time may provide insights into adjunctive therapies useful in treating drug addiction, alcoholism, and other addictions.

\section{Food Urges, Addiction, and Eating Behavior}

Humans eat even when they are not physically hungry as psychological, environmental, and hedonic influences affect food urges. The peripheral and central pathways which regulate food intake are geared toward the storage of calories when food is eaten in excess of metabolic needs, leading to obesity in situations of high fat and sugar food availability coupled with sedentary lifestyles.

Dopamine increases the motivation for food intake in animals and humans as demonstrated by imaging studies carried out using food images [1]. It has also been demonstrated that obese individuals have reduced levels of dopamine D2 receptors and that these are inversely related to body weight [2]. Presentation of desirable foods increases metabolism in the orbitofrontal cortex (OFC), the area of the brain that programs chewing and salivation, in proportion to the subjective perception of hunger and the desire to eat [3]. Obese subjects studied with functional magnetic resonance imaging (fMRI), which detects changes in blood flow, had evidence of activated striatum and OFC as well as the insula while viewing pictures of high-caloric food [4]. Wang and co-workers used positron emission tomography imaging which detects uptake of 2-deoxy-2 $\left[{ }^{18} \mathrm{~F}\right]$ fluoro-D-glucose $\left({ }^{18} \mathrm{FDG}\right)$ to assess the ability of men and women to inhibit the activation of brain metabolism following presentation of images of favorite foods. In men food stimulation with inhibition significantly decreased activation in amygdala, hippocampus, insula, orbitofrontal cortex, and striatum, but this did not occur in women [5]. The regions studied are integral to emotional regulation, conditioning, and motivation of food intake and in men suppressed activation of the orbitofrontal cortex with inhibition was associated with decreased self-reports of hunger. These observations suggest that hormonal mechanisms may underlie a gender difference in the ability to suppress hunger, and may contribute to the greater incidence of obesity in women compared to men.

The repeated stimulation of DA (dopamine) reward pathways has been proposed by Volkow to trigger adaptations in other neurotransmitters and in brain reward circuitry that may lead to increases in compulsive behaviors affecting both food and drug intake [6]. Moreover, exposure to drugs that elicit dependence alters gene expression profiles throughout the reward circuitry of the brain [7]. Drugs of abuse induce repeated profound dopamine stimulation which, with chronic use, may induce changes in neuronal plasticity resulting in increased emotional reactions to drugs and reduced ability to inhibit drug consumption leading to compulsive chronic drug abuse [6]. Sugar-induced dependence in rats has been shown to promote increased consumption of ethanol, suggesting that food-related dependence may influence drug addiction [8]. As reviewed above, repeated exposure to favorite foods, especially those that are calorie dense due to excess sugar and fat could lead to binge eating disorder, and poor inhibitory control of food intake [9]. The increased usage of high fructose corn syrup in the American diet has been further suggested to reduce satiety that would have normally been satisfied with consumption of natural sugars [10]. Studies of rats show that excessive binging on sugar followed by deprivation creates a state of anxiety and suggested opiate-like withdrawal [11]. While both pathways have similarities, there is a need for more research to assess whether they are also interacting. That is, whether addictive drugs affect the emotional reaction to foods and vice versa. Such an interaction could have significance for efforts to combat drug abuse as well as obesity. A possible mechanism for such an interaction is the systemic inflammation associated with obesity which could affect the brain and promote changes that make individuals more susceptible to dopamine-related rewards.

\section{Genetic Polymorphisms Associated with Obesity and Food Addiction}

Consumption of favorite foods increases dopamine concentrations in the nucleus accumbens, activating the mesocorticolimbic dopaminergic reward pathways of the brain, resulting in the reinforcing effects of euphoria or pleasure. These discoveries have been the result of advances in brain imaging including positron emission tomography scan and fMRI that enables visualization of brain activation on simply seeing images of favorite foods.

Since consuming food is critical to survival, it is perfectly reasonable that this activity would be highly valued within our inherited biological control mechanisms that evolved over eons of food scarcity and insecurity. Only in recent times has there been a surplus of calories available to all Americans including those in the lower socioeconomic strata. While these foods are inexpensive, they also have limited nutritional value and excess amounts of sugar and fat. Pleasurable responses to sugar and fat linked to activation of reward circuits in the brain activated by dopamine and other neurotransmitters can lead to food addiction and obesity in susceptible individuals as has been documented for drugs, alcohol, tobacco, sexual activity, and gambling. 


\section{Dopamine Receptor DRD2 Gene}

The D2 dopamine receptor (DRD2) gene has most commonly been linked to alcoholism, although the gene has been associated with other addictive behaviors such as smoking, illicit drug use, gambling, and overeating. The Taq1A polymorphism, the most frequently studied polymorphism, is located more than 10 kilobase-pairs downstream from the coding region of the DRD2 gene at chromosome 11q23. Recent studies have further localized the coding region of Taq1A within the coding region of a neighboring gene, ANKK1 [12].

The D2 dopamine receptor, a G-protein-coupled receptor located on postsynaptic dopaminergic neurons, is centrally involved in reward-mediating and reward-deficiency pathways [13]. The DRD2 gene encodes two molecularly distinct isoforms with distinct functions [14]. Signaling through dopamine D2 receptors governs physiologic functions related to locomotion, hormone production, and drug abuse. D2 receptors are also known targets of antipsychotic drugs that are used to treat neuropsychiatric disorders such as schizophrenia.

By a mechanism of alternative splicing, the D2 receptor gene encodes two molecularly distinct isoforms, D2S and D2L [15]. They are coexpressed in a ratio favoring the long isoform, D2L. D2L differs from D2S by the presence of an additional 29 amino acids within the third intracellular loop. Usiello et al. demonstrated that these receptors have distinct functions in vivo; D2L acts mainly at postsynaptic sites and D2S serves presynaptic autoreceptor functions [14].

There is evidence of a direct association in Taq1A A1 allele carriers with increased body fat and co-morbid substance use disorders. A clinical study found increased prevalence of Taq1A A1 allele in obese patients with other drug dependencies compared to non-abusing obese patients [16]. Among Taq1A A1 allele carriers, D2 receptor stimulation could potentially be effective in reducing craving and reward-seeking [17]. Individualized custom formulations of neutraceuticals have been proposed to "treat" individuals with known genetic deficiencies such as Taq1A A1 allele carriers [18].

Consumption of sweet or fat foods increases dopamine concentrations in the nucleus accumbens [19], activating the mesocorticolimbic dopaminergic reward pathways of the brain [20], resulting in the reinforcing effects of euphoria or pleasure. The A1 allele of the Taq1A polymorphism (rs1800497), located $\approx 10 \mathrm{~kb}$ downstream of the DRD2 gene [12] has been investigated for possible associations with habitual use of alcohol [21, 22], cocaine [23], nicotine [24-27], and opioids [28]. Evidence indicates that individuals carrying this allele have reduced brain D2 receptor density compared with other individuals [29-32]. Adolescent girls shown with pictures of palatable food had weaker activation of the frontal operculum, lateral orbitofrontal cortex, and striatum if they are carriers of the $D R D 2$ $T a q 1 \mathrm{~A}$ A1 allele or the $D R D 4-7 R$ allele. These girls were also at risk for future weight gain [33].

Persistent substance abuse in individuals with the A1 allele may be a form of self-stimulatory behavior that compensates for insufficient dopamine activity [34]. The A1 allele has also been observed to be associated with obesity [35-37]. More research is needed to determine whether the Taq1A genetic polymorphism interacts with other well-known candidate genes for obesity including polymorphisms of the leptin receptor gene and others, and whether these interactive genetic effects could promote the development of obesity-associated inflammation. In turn, systemic inflammation could affect the brain leading to mild depression or other effects which promote continued addictive behaviors.

\section{Leptin Receptor LEP-R Gene}

Other candidate genes for appetite control may interact with the DRD2 A1 allele to increase the likelihood of overeating and obesity. The leptin receptor gene has polymorphisms that affect binding of leptin to the leptin receptor [38]. The leptin receptor gene $(L E P-R$, formerly $O B-R)$ identified in 1995 , is expressed in the hypothalamus and other organs, binds to free-circulating leptin released from adipose tissue, and plays a major role in metabolism and appetite signaling [39]. Genetic variants potentially affecting receptor structure, function, and binding to leptin include three singlenucleotide polymorphisms (SNPs) that result in amino acid substitutions (Lys109Arg (K109R) rs1137100; Gln223Arg (Q223R) rs1137101; and Lys656Asn (K656N) rs8179187) [40-42] located at highly conserved positions in the extracellular domain of the receptor protein.

Research from our group demonstrated an association between percent body fat and the LEP-R variant Lys109Arg [43]. Other studies reported linkage of Lys109Arg with fat mass [44], association with serum leptin levels in young Dutch men [45], an interaction between Lys109Arg and menopause with body mass index (BMI) [46], and fat mass loss in a caloric restriction intervention [47]. While the $D R D 2$ gene increases the likelihood of food addiction and obesity [36, 37], the $L E P-R$ gene influences appetite control and has been associated with elevated levels of body fat and body composition [43-47]. The joint influence of $D R D 2$ and $L E P-R$ could therefore predispose individuals to weight gain and obesity if risk alleles are carried from both genes.

Evidence for potential $D R D 2$ and $L E P-R$ interaction has been demonstrated in mice lacking D2 receptors [48]. D2 receptor knock-out mice demonstrated leptin sensitivity, while wild-type mice had heavier body weights and were 
leptin resistant. Further studies are needed to characterize the interplay between genes that encode for reward/pleasure neurotransmitters and energy balance regulation.

\section{Mu-Opiod Receptor Gene (OPRM1)}

The mu-opioid receptor gene (OPRM1, located on chromosome 6q24) is one of four genes whose protein products bind to endogenous opioids. OPRM1 is a member of the large family of transmembrane G-protein-coupled receptors. It is widely expressed in both brain and periphery [49]. The mu-opioid receptor is the primary site of action for the most commonly used opioids, including morphine, heroin, fentanyl, and methadone. By sequencing, DNA from 113 former heroin addicts in methadone maintenance and 39 individuals with no history of drug or alcohol dependence, five different SNPs in the coding region of the mu-opioid receptor gene were identified. The most prevalent SNP is a nucleotide substitution at position 118 (A118G), predicting an amino acid change at a putative $\mathrm{N}$-glycosylation site. This SNP displays an allelic frequency of approximately $10 \%$ in the study population. Significant differences in allele distribution were observed among ethnic groups studied [50]. In a targeted study of food addiction, the functional A118G polymorphism of the mu-opioid receptor gene was found to be associated with binge eating disorders [51].

\section{Human Diets, Obesity, and Inflammation}

Over the last 200 years, changes in the human diet and lifestyle have outstripped the ability of the genome to adjust to a changing environment and billions of people around the world are now overfat as a result [52-58]. While studies demonstrate that hunter-gatherers ate over 800 varieties of plant foods [59], Americans eat only about three servings per day which fail to provide the naturally occurring antioxidants, phytochemicals, vitamins, and minerals essential to good health. Highly processed foods with refined starches, sugars, fats, and oils often fail to contain essential nutrients found in nutrient-dense foods [60]. At the same time, labor-saving devices of all kinds and advances in transportation have made a highly sedentary lifestyle possible in just the last 30 years [61]. A global epidemic of obesity and chronic disease that is underestimated using the BMI is sweeping the globe as industrialization and improved standards of living are spreading to urban centers. Certain ethnic groups including African-Americans, Asians, Asian Indians, Latinos, Native Americans, and Eastern Europeans are genetically susceptible to Metabolic Syndrome resulting from the accumulation of visceral fat with resulting inflammation [62]. It is estimated that in the next 10 years, the majority of all heart disease will be associated with type 2 diabetes mellitus [63].

The metabolic syndrome has emerged as an important cluster of risk factors for atherosclerotic disease. Common features are central (abdominal) obesity, insulin resistance, hypertension, and dyslipidemia, with high triglycerides and low high-density lipoprotein cholesterol. According to the clinical criteria developed by ATP III, it has been estimated that about one of every four adults living in the USA merits the diagnosis. The presence of the metabolic syndrome is highly prognostic of future cardiovascular events.

Chronic inflammation may represent a triggering factor in the origin of the metabolic syndrome: stimuli such as overnutrition, physical inactivity, and aging would result in cytokine hypersecretion and eventually lead to insulin resistance and diabetes in genetically or metabolically predisposed individuals. Alternatively, resistance to the anti-inflammatory actions of insulin would result in enhanced circulating levels of proinflammatory cytokines resulting in persistent low-grade inflammation. A generally enhanced adipose tissue-derived cytokine expression may be another plausible mechanism for the inflammation/ metabolic syndrome relationship. The role of adipose tissue as an endocrine organ capable of secreting a number of adipose tissue-specific or enriched hormones, known as adipokines, may play a pathogenic role in metabolic syndrome. Although the precise role of adipokines in the metabolic syndrome is still debated, an imbalance between increased inflammatory stimuli and decreased antiinflammatory mechanisms may be an intriguing working hypothesis. The chronic inflammatory state that accompanies the metabolic syndrome associates with both insulin resistance and endothelial dysfunction, providing a connection between inflammation and metabolic processes which is highly deleterious for vascular function. However, small amounts of weight loss which relieve the pressure for abdominal adipocytes to proliferate have been shown to reduce inflammation in patients with type 2 diabetes [64], and in two large trials to reduce the incidence of new cases of diabetes over 5 years by $58 \%$ in individuals with glucose intolerance and insulin resistance [65].

\section{Conclusion}

Our brains are programmed to activate the pleasure centers of the brain on visualizing food and then eating it, to remember the food that was eaten in specialized memory neurons, and to activate our digestive processes including chewing and hormone secretion in preparation for digesting a delicious meal. Eating food is a life-giving event in the wild and so it is perfectly reasonable that this activity 
would be highly valued within our inherited biological control mechanisms. However, when the stimuli are linked in susceptible individuals to increases in reward circuitry activity as detected in changes in dopamine and glucose metabolism, then neuronal plasticity could be altered in ways that both increase the tendency to eating disorders and obesity as well as drug addiction. Whether these pathways interact in susceptible individuals is unknown but has potential significance for efforts to prevent or treat chronic drug abuse through changes in diet and lifestyle including the treatment of obesity which may reduce brain inflammation.

Open Access This article is distributed under the terms of the Creative Commons Attribution Noncommercial License which permits any noncommercial use, distribution, and reproduction in any medium, provided the original author(s) and source are credited.

\section{References}

1. Volkow ND, Wang GJ, Fowler JS, Logan J, Jayne M, Franceschi D, Wong C, Gatley SJ, Gifford AN, Ding YS, Pappas N (2002) "Nonhedonic" food motivation in humans involves dopamine in the dorsal striatum and methylphenidate amplifies this effect. Synapse 1:175-180

2. Wang G-J, Volkow ND, Logan J, Pappas NR, Wong CT, Zhu W, Netusil N, Fowler JS (2001) Brain dopamine and obesity. Lancet 357:354-357

3. Wang GJ, Volkow ND, Telang F, Jayne M, Ma J, Rao M, Zhu W, Wong CT, Pappas NR, Geliebter A, Fowler JS (2004) Exposure to appetitive food stimuli markedly activates the human brain. Neuroimage 21:1790-1797

4. Rothemund Y, Preuschhof C, Bohner G, Bauknecht HC, Klingebiel R, Flor H, Klapp BF (2007) Differential activation of the dorsal striatum by high-calorie visual food stimuli in obese individuals. Neuroimage 215:410-421

5. Wang GJ, Volkow ND, Telang F, Jayne M, Ma Y, Pradhan K, Zhu W, Wong CT, Thanos PK, Geliebter A, Biegon A, Fowler JS (2009) Evidence of gender differences in the ability to inhibit brain activation elicited by food stimulation. Proc Natl Acad Sci USA 106:1249-1254

6. Volkow ND, Li TK (2004) Science and society: drug addiction: the neurobiology of behaviour gone awry. Nat Rev Neurosci 5:963-970

7. Maze I, Nestler EJ (2011) The epigenetic landscape of addiction. Ann NY Acad Sci 1216:99-113

8. Avena NM, Carrillo CA, Needham L, Hoebel BG (2004) Sugardependent rats show enhanced intake of unsweetened ethanol. Alcohol 34:203-209

9. Avena NM, Rada P, Hoebel BG (2008) Evidence for sugar addiction: behavioral and neurochemical effects of intermittent, excessive sugar intake. Neurosci Biobehav Rev 32:20-39

10. Bocarsly ME, Powell ES, Avena NM, Hoebel BG (2010) High fructose corn syrup causes characteristics of obesity in rats: Increased body weight, body fat, and triglyceride levels. Pharmacol Biochem Behav 97:101-106

11. Avena NM, Bocarsly ME, Rada P, Kim A, Hoebel BG (2008) After daily bingeing on a sucrose solution, food deprivation induces anxiety and accumbens dopamine/acetylcholine imbalance. Physiol Behav 94:309-315
12. Neville MJ, Johnstone EC, Walton RT (2004) Identification and characterization of ANKK1: a novel kinase gene closely linked to DRD2 on chromosome band 11q23.1. Hum Mutat 23:540-545

13. Blum K, Sheridan PJ, Wood RC, Braverman ER, Chen TJH, Cull JG, Comings DE (1996) The D2 dopamine receptor gene as a determinant of reward deficiency syndrome. J R Soc Med 89:396-400

14. Usiello A, Baik JH, Rouge-Pont F, Picetti R, Dierich A, LeMeur M, Piazza PV, Borreli E (2000) Distinct functions of the two isoforms of dopamine D2 receptors. Nature 408:199-203

15. Picetti R, Sairdi A, Abdel ST, Bozzi Y, Baik JH, Borreli E (1997) Dopamine D2 receptors in signal transduction and behavior. Crit Rev Neurobiol 11:121-142

16. Blum K, Braverman ER, Wood RC, Gill J, Li C, Chem TJH, Taub M, Montgomery AR, Sheridan PJ, Cull JG (1996) Increased prevalence of the TaqI A1 allele of the dopamine receptor gene (DRD2) in obesity with comorbid substance abuse disorder: a preliminary report. Pharmacogenetics 6:297-305

17. Downs BWQ, Chem ALC, Chen TJH, Waite RL, Braverman ER, Kerner M, Braverman D, Rhoades P, Prihoda RJ, Palomo T, Oscar-Bernam M, Reinking J, Blum SH, DiNubile NA, Liu HH, Blum K (2009) Nutrigenomic targeting of carbohydrate craving behavior: Can we manage obesity and aberrant craving behaviors with neurochemical pathway manipulation by Immunological Compatible Substances (nutrients) using a Genetic Positioning System (GPS) map? Med Hypotheses 73:427-434

18. Blum K, Chen TJH, Williams L, Chen ALC, Downs WB, Waite RL, Huntington T, Sims S, Prihoda R, Reinking J, Braverman D, Kerner M, Blum SH, Quirk B, Braverman ER (2008) A short term pilot open label study to evaluate efficacy and safety of LG839, a customized DNA directed nutraceuticals in obesity: Exploring Nutrigenomics. Gene Ther Mol Biol 12:371-381

19. Bassareo V, Di Chiara G (1999) Differential responsiveness of dopamine transmission to food-stimuli in nucleus accumbens shell/core compartments. Neuroscience 85:637-641

20. Hoebel BG (1985) Brain neurotransmission in food and drug reward. Am J Clin Nutr 42:1133-1150

21. Munafò MR, Matheson IJ, Flint J (2007) Association of the DRD2 gene Taq1A polymorphism and alcoholism: a metaanalysis of case-control studies and evidence of publication bias. Mol Psychiatry 12:454-461

22. Blum K, Noble EP, Sheridan PJ, Montgomery A, Ritchie T, Ozkaragoz $\mathrm{T}$ et al (1993) Genetic predisposition in alcoholism: association of the $\mathrm{D}_{2}$ dopamine receptor TaqI B1 RFLP with severe alcoholics. Alcohol 10:59-67

23. Noble EP, Blum K, Khalsa ME, Ritchie T, Montgomery A, Wood $\mathrm{RC}$ et al (1993) Allelic association of the D2 dopamine receptor gene with cocaine dependence. Drug Alcohol Depend 33:271-285

24. Noble EP, St Jeor ST, Ritchie T, Syndulko K, St Jeor SC, Fitch RJ, Brunner RL, Sparkes RS (1994) D2 dopamine receptor gene and cigarette smoking: a reward gene? Med Hypotheses 42:257-260

25. Comings DE, Ferry L, Bradshaw-Robinson S, Burchette R, Chiu C, Muhleman D (1996) The dopamine D2 receptor (DRD2) gene: a genetic risk factor in smoking. Pharmacogenetics 6:73-79

26. Gelernter J, Yu Y, Weiss R, Brady K, Panhuysen C, Yang BZ, Kranzler HR, Farrer L (2006) Haplotype spanning TTC12 and ANKK1, flanked by the DRD2 and NCAM1 loci, is strongly associated to nicotine dependence in two distinct American populations. Hum Mol Genet 15:3498-3507

27. Munafò M, Clark T, Johnstone E, Murphy M, Walton R (2004) The genetic basis for smoking behavior: a systematic review and meta-analysis. Nicotine Tob Res 6:583-597

28. Lawford BR, Young RM, Noble EP, Sargent J, Rowell J, Shadforth S, Xhang X, Ritchie T (2000) The D2 dopamine receptor A1 allele and opioids dependence: association with heroin use and response to methadone treatment. Am J Med Genet 96:592-598 
29. Jönsson EG, Nöthen MM, Gründhage F, Farde L, Nakashima Y, Propping P, Sedval GC (1999) Polymorphisms in the dopamine D2 receptor gene and their relationships to striatal dopamine receptor density of healthy volunteers. Mol Psychiatry 4:290-296

30. Noble EP, Blum K, Ritchie T, Montgomery A, Sheridan PJ (1991) Allelic association of the D2 dopamine receptor gene with receptor-binding characteristics in alcoholism. Arch Gen Psychiatry 48:648-654

31. Pohjalainen T, Rinne JO, Nagren K, Lehikoinen P, Anttila K, Syvalahti EK, Hietala J (1998) The A1 allele of the human D2 dopamine receptor gene predicts low D2 receptor availability in healthy volunteers. Mol Psychiatry 3:256-260

32. Thompson J, Thomas N, Singleton A, Piggott M, Lloyd S, Perry EK et al (1997) D2 dopamine receptor gene (DRD2) Taq1 A polymorphism: reduced dopamine D2 receptor binding in the human striatum associated with the A1 allele. Pharmacogenetics $7: 479-484$

33. Stice E, Yokum S, Bohon C, Marti N, Smolen A (2010) Reward circuitry responsivity to food predicts future increases in body mass: moderating effects of DRD2 and DRD4. Neuroimage 50:1618-1625

34. Comings DE, Blum K (2000) Reward deficiency syndrome: genetic aspects of behavioral disorders. Prog Brain Res 126:325-341

35. Comings DE, Gade R, MacMurray JP, Mulhalman D, Peters WR (1996) Genetic variants of the human obesity (OB) gene: association with body mass index in young women, psychiatric symptoms, and interaction with the dopamine D2 receptor (DRD2) gene. Mol Psychiatry 1:325-335

36. Noble EP, Noble RE, Ritchie T, Syndulko K, Bohlman MC, Noble LA et al (1994) Allelic association of the human D2 dopamine receptor gene with obesity. Int J Eat Disord 15:205-217

37. Spitz MR, Detry MA, Pillow P, Hu YH, Amos CI, Hong WK, Wu XF (2000) Variant alleles of the D2 dopamine receptor gene and obesity. Nutr Res 20:371-380

38. Caro JF, Sinha MK, Kolaczynski JW, Zhang PL, Considine RV (1996) Leptin: the tale of an obesity gene. Diabetes 45:1455-1462

39. Tartaglia LA (1997) The leptin receptor. J Biol Chem 272:6093-6096

40. Francke S, Clement $\mathrm{K}$, Dina $\mathrm{C}$, Inoue $\mathrm{H}$, Behn $\mathrm{P}$, Vatin $\mathrm{V}$, Basdevant A, Guy-Grand B, Permutt MA, Froguel P, Hager J (1997) Genetic studies of the leptin receptor gene in morbidly obese French Caucasian families. Hum Genet 100:491-496

41. Chung WK, Power-Kehoe L, Chua M, Chu F, Aronne L, Huma Z, Sothern MN, Udall B, Kahle B, Leibel RL (1997) Exonic and intronic sequence variation in the human leptin receptor gene (LEPR). Diabetes 46:1509-1511

42. Thompson DB, Ravussin E, Bennett PH, Bogardus C (1997) Structure and sequence variation at the human leptin receptor gene in lean and obese Pima Indians. Hum Mol Genet 6:675-679

43. Carpenter CL, Ingles S, Jaque V, Schroeder E, Wong HL, Bernstein L (2004) Obesity and leptin-receptor gene polymorphisms among postmenopausal women. FASEB J 18(Suppl A):384

44. Chagnon YC, Wilmore JH, Borecki IB, Gagnon J, Pérusse L, Chagnon M, Collier GR, Leon AS, Skinner JS, Rao DC, Bouchard C (2000) Associations between the leptin receptor gene and adiposity in middle-aged Caucasian males from the HERITAGE family study. J Clin Endocrinol Metab 85:29-34

45. van Rossum CT, Hoebee B, van Baak MA, Mars M, Saris WH, Seidell JC (2003) Genetic variation in the leptin receptor gene, leptin, and weight gain in young Dutch adults. Obes Res 11:377-386

46. Wauters M, Mertens I, Chagnon M, Rankinen T, Considine RV, Chagnon YC, Van Gaal LF, Bouchard C (2001) Polymorphisms in the leptin receptor gene, body composition and fat distribution in overweight and obese women. Int $\mathrm{J}$ Obes $25: 714-720$
47. Abete I, Goyenechea E, Crujeiras AB, Martinez JA (2009) Inflammatory state and stress condition in weight-lowering Lys 109Arg LEPR gene polymorphism carriers. Arch Med Res 40:306-310

48. Kim KS, Yoon YR, Lee HJJ, Yoon S, Kim S-Y, Shin SW, An JJ, Kim M-S, Choi S-Y, Sun W, Bail J-H (2010) Enhanced hypothalamic leptin signaling in mice lacking dopamine D2 receptors. J Biol Chem 285:8905-8917

49. Berettini W (2005) The human mu opiod receptor gene in addictions. Clin Neurosci Res 5:69-73

50. Bond C, LaForge KS, Tian M, Melia D, Zhang S, Borg L, Gong J, Schluger J, Strong JA, Leal SM, Tischfield JA, Kreek MJ, Yu L (1998) Single-nucleotide polymorphism in the human mu opiod receptor gene alters beta-endorphin binding and activity: possible implications for opiate addiction. Proc Natl Acad Sci 95:9608-9613

51. Davis CA, Levitan RD, Reid C, Carter JC, Kaplan AS, Oattie KA, King N, Curtis C, Kennedy JL (2009) Dopamine for "wanting" and opiods for "liking": a comparison of obese adults with and without binge eating. Obesity 17:1220-1225

52. Gross LS, Li L, Ford ES, Liu S (2004) Increased consumption of refined carbohydrates and the epidemic of type 2 diabetes in the United States: an ecologic assessment. Am J Clin Nutr 79:774-779

53. Bray GA, Nielsen SJ, Popkin BM (2004) Consumption of highfructose corn syrup in beverages may play a role in the epidemic of obesity. Am J Clin Nutr 79:537-543

54. Bray GA, Popkin BM (1998) Dietary fat intake does affect obesity! Am J Clin Nutr 68:1157-1173

55. Darmon N, Briend A, Drewnowski A (2004) Energy dense diets are associated with lower diet costs: a community study of French adults. Public Health Nutr 7:21-27

56. Drewnowski A (2003) Fat and sugar: an economic analysis. J Nutr 133:838S-840S

57. Drewnowski A (2004) Obesity and the food environment: dietary energy density and diet costs. Am J Prev Med 94:1555-1559

58. World Health Organization. (2003) Diet, nutrition and the prevention of chronic diseases. Report of a joint WHO/FAO consultation. Geneva, Switzerland. Technical report 916. www. who.int/dietphysicalactivity/publications/trs916/intro/en/. Accessed 25 Mar 2011

59. Brand-Miller JC, Holt SH (1998) Australian Aboriginal plant foods: a consideration of their nutritional composition and health implications. Nutr Res Rev 11:5-23

60. Kant AK (2000) Consumption of energy-dense, nutrient-poor foods by adult Americans: nutritional and health implications. The third National Health and Nutrition Examination Survey, 19881994. Am J Clin Nutr 72:929-936

61. Hill JO, Wyatt HR, Reed GW, Peters JC (2003) Obesity and the environment: where do we go from here? Science 299:853-855

62. Seidell JC (2000) Obesity, insulin resistance and diabetes-a worldwide epidemic. Br J Nutr 83:S5-S8

63. Bax JJ, van der Wall EE (2006) Assessment of coronary artery disease in patients with (a)symptomatic diabetes. Eur Heart J 27:631-632

64. Li Z, Hong K, Saltsman P, DeShields S, Bellman M, Thames G, Liu Y, Wang HJ, Elashoff R, Heber D (2005) Long-term efficacy of soy-based meal replacements vs an individualized diet plan in obese type II DM patients: relative effects on weight loss, metabolic parameters, and C-reactive protein. Eur J Clin Nutr $59: 411-418$

65. Knowler WC, Barrett-Connor E, Fowler SE, Hamman RF, Lachin JM, Walker EA, Nathan DM, Diabetes Prevention Program Research Group (2007) Reduction in the incidence of type 2 diabetes with lifestyle intervention or metformin. N Engl J Med 346:393-403 